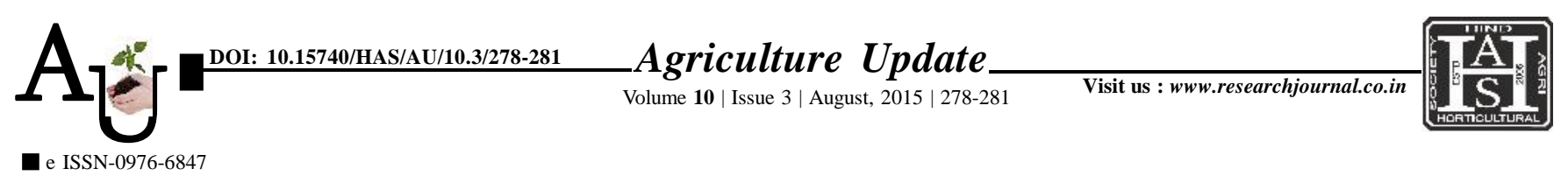

\title{
A Cass Stupx: Crop intensification in rainfed farming system of tribal district of Kanker of Chhattisgarh state
}

\author{
BIRBAL SAHU, RAMA MOHAN SAVU, ATUL DANGE AND G.P. PALI
}

Article Chronicle: Received :

27.05.2015;

Revised :

28.07.2015;

Accepted :

25.08.2015

KeY Words :

Crop intensification, Biasi, Livelihood, Line sowing

Author for correspondence :

\section{BIRBAL SAHU}

Krishi Vigyan Kendra, Singarbhat, KANKER (C.G.) INDIA

Email: bbsahu71@gmail. com

See end of the article for authors' affiliations
SUMMARY : The rice is an important food crop of Kanker district mainly grown as direct broadcast seeding under dry conditions. About 61 per cent of the total rice area in the district is sown by this method. After onset of monsoon, farmers broadcast paddy seed and plough by desi plough or tractor drawn cultivator. Bueshening (blind hoeing or biasi) is widely practiced in the district which covers about 80 per cent of the rice area. Thus, there is need to replace the biasi system by line sowing. This method of sowing with early maturing rice variety helps in establishment of succeeding Rabi crop which gave additional return to farmers in turn improves his socio-economic condition and livelihood status. To overcome the problem, KVK, Kanker (C.G.) has started dry line sowing of paddy by seed cum fertilizer drill with post-emergence application of herbicide and establishment of succeeding chickpea crop in residual moisture. Line sowing of rice variety MTU-1010 followed by chickpea variety 'Vaibhav' was compared with farmer's practice of broadcasting rice with biasi system. Results across sites from 2009-10 to 2012-13 showed that the direct seeding in line + application of post-emergence herbicide gave the most consistent yield ranging from 30.30 to $34.75 \mathrm{q} / \mathrm{h}$ a than the farmers practice. In addition to the rice yield, the improved practice gave a chickpea yield ranging from 2.00 to $2.50 \mathrm{q} / \mathrm{ha}$. In terms of cropping system performance, the rice equivalent yield ranged from 36.66 to $40.47 \mathrm{q} / \mathrm{ha}$. The improved practice rewarded additional net return of Rs. 10287/ha over farmers practice. Benefit: Cost ratio was 2.81 and 3.42 under farmer and improved practice, respectively.

How to cite this article : Sahu, Birbal, Savu, Rama Mohan, Dange, Atul and Pali, G.P. (2015). Crop intensification in rainfed farming system of tribal district of Kanker of Chhattisgarh state. Agric. Update, 10(3): 278-281. 